\title{
ELŐSZÓ A POLITIKAI KOMMUNIKÁCIÓ ÉS EXPRESSZIVITÁS TEMATIKUS BLOKKHOZ
}

\author{
Szabó Gabriella
}

A politikai kommunikáció és expresszivitás összefüggéseiről szóló tanulmányokat tárunk az olvasó elé. Mindegyik írás az érzelemkifejezések, illetve a megszólások tárgyával kapcsolatos személyes viszonyulások nyilvánossá tételének módját és jellemzőit vizsgálja. A blokk cikkei a Társadalomtudományi Kutatóközpont Politikatudományi Intézetében múködő Politikai Kommunikáció Kutatócsoport 2019 decemberében indult projektjének első termékei. S mint ilyenek, fóként elméleti és konceptualizációs céllal íródtak. Két tanulmányunk kutatási adatokat is bemutat, ezek feltáró-leíró vizsgálatok eredményei, és mintegy illusztratív példaként szolgálnak a felvezetett témák tárgyalásához.

Az első cikk az expresszivitás fogalmát járja körül. Szabó Gabriella és Kiss Balázs az érzelemtelített, expresszív politikai kommunikáció vizsgálatának alapjait és lehetséges irányait vázolja. Szabó Gabriella és Farkas Xénia az expresszivitás egyik prototipikus megvalósulásáról, a modortalanságról írnak. Burai Krisztina és Bene Márton a politikai kommunikáció expresszív és fatikus funkciójának együtt járását mutatják be a 2018-as országgyúlési választáso kat megelőző kampányok időszakában felvett közösségi média adatokra építve. A blokkot Kiss Balázs, Szabó Lilla és Farkas Xénia írása zárja. A szerzőhármas a nyilvánosságban megjelenő érzelmi kommunikáció speciális típusáról, az áldozatképzésről közöl kutatást. A blokk szerkesztője Szabó Gabriella. A vizsgálatok háttérét az NKFIH-FK 131990 témaszámú projekt adja.

A tanulmányok korábbi változatait 2020. szeptember 15-én online workshopon megvitattuk. Szerzőtársaim nevében köszönöm szépen a rendezvény résztvevőinek, hogy kritikai megjegyzéseikkel segítették a munkánkat. Hálásak vagyunk a Politikatudományi Szemle által felkért bírálók értékes hozzászólásaiért. Végül, de nem utolsósorban köszönettel tartozunk a szerkesztőség nyitottságáért és együttmúködéséért. 